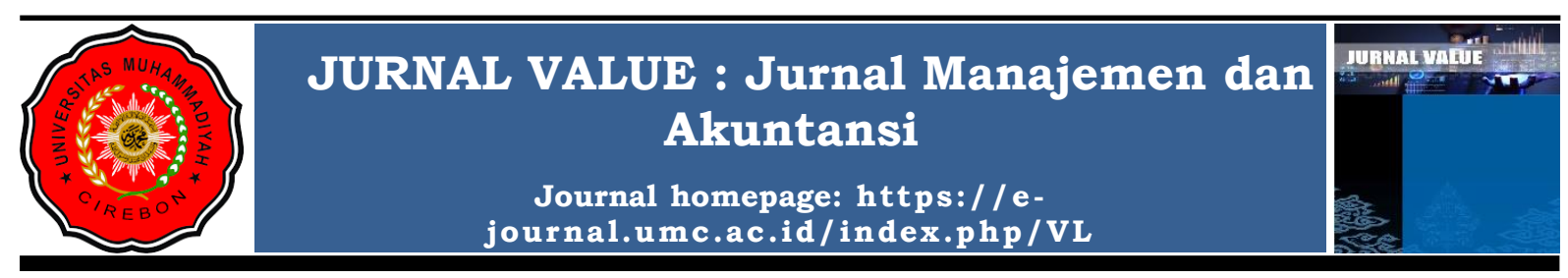

\title{
Pengaruh Kepemimpinan Paternalistik Terhadap Kinerja Tugas dan Kontekstual Karyawan; Pemediasi Rasa Percaya
}

\author{
Anhar Januar Malik ${ }^{1}$ \\ Iskandar Arifin ${ }^{2}$ \\ ${ }^{1}$ Menejemen Retail, Institut Teknologi dan Bisnis Kalla \\ Email : anharjm@kallabs.ac.id \\ ${ }^{2}$ Menejemen Retail, Institut Teknologi dan Bisnis Kalla \\ Email : iskandara@kallabs.ac.id
}

Diterima : 15 November 2021 Direvisi : 25 November 2021 Dipublikasikan : 31 Desember 2021

\begin{abstract}
Abstrak
Salah satu topik dalam kajian kepemimpinan yang mendapat banyak perhatian saat ini adalah kepemimpinan internasional, dimana para peneliti memfokuskan pada perilaku kepemimpinan yang sesuai dengan budaya dimana organisasi tersebut berada. Kepemimpinan paternalistik menjadi salah satu tema dalam kajian kepemimpinan internasional. Penelitian ini menjelaskan mengenai mekanisme bagaimana kepemimpinan paternalistik mempengaruhi kinerja tugas dan kinerja kontekstual karyawan menggunakan teori pertukaran sosial dan teori kejadian afektif pada konteks organisasi. 193 tanggapan valid karyawan dari berbagai organisasi ikut ambil bagian dalam penelitian ini. Hasil analisis data menunjukkan perilaku kepemimpinan paternalistik memiliki pengaruh positif pada kinerja tugas dan kinerja kontekstual karyawan. Selanjutnya, rasa percaya pada pemimpin memediasi secara parsial pengaruh kepemimpinan paternalistik pada kinerja tugas dan memediasi secara penuh pengaruh kepemimpinan paternalistik dan kinerja kontekstual karyawan. Temuan ini menunjukkan bahwa semakin tinggi kepemimpinan paternalistik maka akan meningkatkan rasa percaya karyawan pada pemimpin, kemudian melalui rasa percaya pada pemimpin inilah kinerja karyawan juga akan meningkat. Adapun argumentasi dalam menjelaskan hasil tersebut lebih detail dibahas pada bagian diskusi artikel ini.
\end{abstract}

Kata kunci: Kepemimpinan, paternalistik, kinerja, kepercayaan,mediasi

\section{PENDAHULUAN}

Pandemi Covid-19 menjadi bencana yang tidak hanya memengaruhi masyarakat namun juga perilaku yang ada dalam organisasi. Kepemimpinan yang kuat dalam sebuah orgnisasi memegang peranan penting dalam kesuksesan organisasi dimasa pandemi. Sejalan dengan hal tersebut tulisan Kerrissey \& Edmondson, (2020) pada Harvard Business Review yang berjudul "what good leadership looks like during this pandemic" menjelaskan bahwa saat ini dibutuhkan perilaku kepemimpinan yang unik untuk melawan kecenderungan alami manusia untuk meremehkan pandemi dan menunda pekerjaan. Pandemi Covid-19 menuntut organisasi menemukan formulasi khusus untuk menjaga produktifitas dan yang paling utama menjaga keselamatan karyawan. Kepemimpinan merupakan salah satu aspek yang memegang peranan penting dalam sebuah organisasi dalam mencapai tujuannya. Beberapa penelitian terkait kepemimpinan menunjukkan bahwa perbedaan budaya, nilai, norma dan faktor kontekstual menyebabkan perbedaan pengaruh/respon terhadap kepemimpinan (Irawanto et al., 2012).

Kepemimpinan merupakan aspek penting dalam sebuah organisasi, perilaku kepemimpinan dianggap menjadi salah satu kunci dalam kesuksesan organisasi tidak hanya dalam menjaga produktifitas anggotanya tetapi juga bagaimana perannya terhadap keselamatan para anggota dimasa 
pandemi. Indonesia sebagai negara yang mengatut budaya high power distance dan collectivist (Hofstade, 2020), akan merespon berbeda perilaku kepemimpinan dalam sebuah organisasi. Harapan akan adanya delegasi/partisipasi akan kecil dan cenderung mengharapkan ketegasan dari pembuat keputusan yang otoriter. Lebih lanjut, keterlibatan pemimpin pada kehidupan personal diinginkan dan diharapkan, yang mana hal tersebut akan dianggap sebagai pelanggaran privasi pada negara dengan nilai individualisme tinggi (Aycan, 2006). Oleh karena itu, diperlukan penelitian yang mampu menjelaskan model kepemimpinan yang sesuai dengan budaya yang ada khususnya yang sesuai dengan budaya di Indonesia.

Kepemimpinan paternalistik terbukti secara empiris memberikan dampak positif bagi organisasi dengan membentuk sikap dan perilaku positif karyawan (M. Wu et al., 2012). Hal ini sejalan dengan teori pertukaran sosial yang dikembangkan oleh Blau, dimana norma timbal balik yang menjelaskan bahwa orang-orang secara umum termotivasi untuk membalas perilaku yang menguntungkan berdasar pada rasa hutang budi dan merasa memiliki kewajiban membalas orang yang memberikan batuan (Chen et al., 2011). Lebih lanjut, dalam memahami bagaimana mekanisme perilaku kepemimpinan paternalistik memengaruhi kinerja bawahan, diperlukan eksplorasi terhadap mediator potensial, hal ini juga sejalan dengan beberapa saran penelitian sebelumnya untuk mencari alternatif mediator (Cheng et al 2004, chan, 2007; wu et al., 2012). Oleh karena itu, perlu adanya sebuah model yang dapat menjelaskan bagaimana mekanisme kepemimpinan paternalistik dan keluarnya (Y.-C. Wu \& Tsai, 2012).

Kondisi pandemi memaksa beberapa pekerja untuk bekerja dari rumah, karyawan yang bekerja dari rumah dapat berdampak pada penurunan kinerja disebabkan oleh adanya jarak dan pola komunikasi yang berubah baik itu dengan rekan kerja maupun dengan pimpinanya (Baruch, Wilson \& Grenhill). Lebih lanjut menurut Wojcak et al. menjelaskan bahwa secara bertahap seseorang karyawan akan kehilangan motivasi dan selanjutnya kinerja yang rendah. Nakrosiene, Buciuniene, \& Gostautaite menyebutkan bahwa selain komunikasi, dukungan dan kesesuaian tempat kerja, kepercayaan juga menjadi faktor kerja jarak jauh yang paling penting. Sejalan dengan hal tersebut rasa percaya dalam kajian kepemimpinan dianggap mampu menjelaskan mekanisme bagaimana perilaku kepemimpinan dan kinerja karyawan saling mempengaruhi (Dirks \& Ferrni, 2002; Burke et al., 2007; Sawar et al., 2015). Mekanisme perilaku kepemimpinan mempengaruhi kinerja tugas dan kinerja kontekstual didasarkan pada proses interaksi pertukaran sosial dimana proses ini akan melahirkan rasa percaya pada pemimpin (Colquitt et al., 2007).

Adanya rasa percaya pada pemimpin oleh karyawan disebabkan perilaku kepemimpinan paternalistik yang ditunjukkan oleh pimpinannya akan memacu karyawan untuk menunjukkan kinerja yang lebih baik. Hal ini sejalan dengan Weiss \& Cropanzano (1996) dalam teori kejadian afektif, bahwa stimulus positif yang dirasakan karyawan berdampak pada sikap positif yang kemudian akan mempengaruhi perilaku positif. Jika dikaitkan pada penelitian perilaku kepemimpinan paternalistik akan menjadi sebuah stimulus yang berdampak pada rasa percaya pada pemimpin sebagai sikap positif yang pada akhirnya akan mempengaruhi kinerja tugas dan kinerja kontekstual karyawan sebagai sebuah perilaku positif.

\section{KAJIAN PUSTAKA DAN PEGEMBANGAN HIPOTESIS}

\section{Kepemimpinan Paternalistik}

Kepemimpinan paternalistik didefinisikan sebagai perilaku yang mengombinasikan disiplin dan otoritas yang kuat dengan kebajikan yang bersifat kebapakan dan integritas moral yang dibingkai dalam suasana personal (Cheng et al., 2004). Sejalan dengan definisi tersebut, akumulasi penelitian telah menunjukkan bahwa kepemimpinan paternalistik bukanlah konstruk uni-dimensi, namun terdiri dari tiga dimensi (kebajikan, otoriter, moral) (Irawanto et al., 2012). Dimensi otoriter dicirikan dengan dinamika hirarkis antara kontrol, kekuatan, dan otoritas pemimpin, dan kepatuhan, pemenuhan dan penghormatan karyawan (L. J. L. Farh et al., 2006). Pemimpin diharapkan untuk menunjukkan kontrol dan wewenang dengan menetapkan peraturan, menentukan tanggung jawab dan menghasilkan hukuman dan penghargaan(Cheng et al., 2013a).

Dimensi kebajikan mengacu pada perilaku kepemimpinan yang menunjukkan kepedulian individu terhadap kebutuhan pribadi atau kesejahteraan keluarga (Simon, 2008). Perilaku dimensi kebajikan pemimpin adalah bentuk investasi dalam hubungan sosial mereka dengan karyawan dengan 
menunjukkan perhatian pada individu dan keseluruhan jika karyawan tersebut menghadapi masalah pekerjaan atau masalah pribadi (seperti masalah keluarga). Dimensi moral mengacu pada perilaku pemimpin yang menunjukkan kepribadian yang kuat, disiplin diri, dan tidak mementingkan diri sendiri (Simon, 2008). Farah dan Cheng juga mendefinisikan dimensi moral sebagai pemimpin yang tidak egois, bertanggung jawab, memberi contoh perilaku yang sesuai, dan memisahkan antara kepentingan bisnis dan pribadi (Y.-C. Wu \& Tsai, 2012). Pemimpin yang menunjukkan nilai moral tinggi akan menjadi contoh yang baik bagi karyawan (Chen et al., 2011).

Berbagai temuan penelitian menunjukkan bahwa pengukuran kepemimpinan paternalistik dalam dimensi tidak mencerminkan keseluruhan perilaku kepemimpinan paternalistik (Chen et al., 2011). Hal ini sejalan dengan Pellegrini dan Scandura yang menjelaskan bahwa ketika kesimpulan diambil dari beberapa dimensi saja akan ada perdebatan karena peneliti benar-benar menguji domain kepemimpinan berbeda (Pellegrini \& Scandura, 2008). Pengukuran persepsi karyawan terhadap kepemimpinan paternalistik harus dilihat dalam rangkaian tunggal (Wagstaff et al., 2015).

\section{Kinerja}

Kinerja individu merupakan konsep inti yang terdapat dalam psikologi kerja dan organisasi. Kinerja sendiri menurut Sonnentag harus ada pemisahan antara aspek perilaku dan aspek kinerja. Aspek perilaku mengacu pada apa yang seseorang lakukan dalam situasi kerja. Tidak semua perilaku termasuk dalam konsep kinerja, tetapi hanya perilaku yang relevan dengan tujuan organisasi. Campbell mendefinisikan kinerja sebagai apa yang organisasi tugaskan untuk seseorang lakukan dan melakukannya dengan baik.(Sonnentag, 2002).

Pembagian konsep kinerja interpersonal yang paling dasar adalah konsep Borman dan Motowidlo yang membedakan antara kinerja tugas dan kinerja kontekstual. Terdapat tiga asumsi yang berhubungan dengan perbedaan antara kinerja tugas dan kinerja kontekstual, yaitu (1) aktivitas yang relevan dengan kinerja tugas beragam antara pekerjaan satu dan yang lainnya sedangkan kinerja kontekstual aktivitasnya relatif sama antar pekerjaan; (2) kinerja tugas berhubungan dengan kemampuan, sementara kinerja kontekstual berhubungan dengan kepribadian dan motivasi; (3) kinerja tugas adalah hal yang telah ditentukan dan merupakan perilaku in-role, sementara kinerja kontekstual adalah hal yang lebih diskresioner dan merupakan perilaku extrarole (Borman \& Motowidlo, 2009).

\section{Rasa Percaya Pada Pemimpin}

Rasa percaya antar pribadi adalah fenomena yang meresap (pervasive) dalam kehidupan organisasi. terdapat tiga hal kunci terkait dengan rasa percaya menurut para ahli. Pertama, keinginan untuk menerima kerentanan. Kedua, tanpa adanya pengawasan, selalu ada ekspektasi positif. Ketiga, penilaian atas individu lain didasarkan pada niat, ketulusan, motivasi, karakter, kehandalan dan integritas. Rasa percaya interpersonal memiliki fondasi kognitif dan afektif Rasa percaya afektif mengacu pada sebuah hubungan spesial dengan orang yang akan dipercayai yang menunjukkan perhatian tentang kesejahteraan seseorang. Sedangkan rasa percaya kognitif mengacu pada isu terkait reliabilitas, integritas, kejujuran dan keadilan dari seorang yang akan dipercayai (Dirks \& Ferrin, 2002).

Penelitian terdahulu kepemimpinan paternalistik seperti pada Tabel 2.1 menunjukkan mayoritas pengukuran kepemimpinan paternalistik secara dimensional yang mana dianggap kurang menggambarkan pengaruh keseluruhan perilaku kepemimpinan (level pengujian keseluruhan dimensi). Lebih lanjut, Tabel 1 menunjukkan kurangnya penelitian yang menjelaskan mekanisme bagaimana perilaku kepemimpinan paternalistik dan kinerja sebagai keluaran.

Pemimpin yang hanya berfokus pada hasil pekerjaan karyawan dan tidak memerhatikan karyawannya seperti perasaan yang dirasakan karyawan dianggap gagal dalam membuat karyawan melakukan usaha yang maksimal dalam menyelesaikan pekerjaan (Cummings et al., 2010). Kepemimpinan paternalistik sangat memerhatikan kepentingan karyawan, baik itu di dalam maupun di luar konteks kerja. Kepemimpinan paternalistik dapat meningkatkan motivasi dari karyawan dan membuat mereka memfokuskan perhatian pada pencapaian dan kinerja sebagai respon terhadap pengakuan yang diterimanya dari pemimpin (Irawanto et al., 2012).

Tabel 1 Level Pengujian dan Pengukuran Kepemimpinan Paternalistik

\begin{tabular}{cccc}
\hline Peneliti & $\begin{array}{c}\text { Pengukuran } \\
\text { Kepemimpinan } \\
\text { Paternalistik }\end{array}$ & Variabel Keluaran & Rujukan Pengukuran \\
\hline Aycan et al. (2000) & Paternalisme & $\begin{array}{c}\text { Partisipasi, Proaktif, Kewajiban } \\
\text { Terhadap Orang Lain }\end{array}$ & Aycan et al. (2000) \\
\hline
\end{tabular}




\begin{tabular}{|c|c|c|c|}
\hline $\begin{array}{l}\text { Aycan Kanungo \& } \\
\text { Sinha (1999) }\end{array}$ & Paternalisme & $\begin{array}{c}\text { Otonomi, Penetapan Tujuan, } \\
\text { Pemberdayaan, Kinerja Ekstrinsik, } \\
\text { Partisipasi }\end{array}$ & $\begin{array}{l}\text { Mathur, Aycan \& } \\
\text { Kanungo (1996) }\end{array}$ \\
\hline Chan (2014) & $\begin{array}{l}\text { Kebajikan, Otoriter, } \\
\text { Moral } \\
\text { (dimensional) }\end{array}$ & Pendapat/Suara Karyawan & Cheng et al. (2000) \\
\hline Cheng et al. (2004) & $\begin{array}{l}\text { Kebajikan, Otoriter, } \\
\text { Moral } \\
\text { (dimensional) }\end{array}$ & $\begin{array}{l}\text { Identifikasi, Pemenuhan, Rasa } \\
\text { Hormat }\end{array}$ & Cheng et al. (2000) \\
\hline Cheng et al. (2002) & $\begin{array}{l}\text { Kebajikan, Otoriter, } \\
\text { Moral } \\
\text { (dimensional) }\end{array}$ & PKO & Cheng et al. (2000) \\
\hline $\begin{array}{l}\text { Cheng, Huang \& } \\
\text { Chou (2002) }\end{array}$ & $\begin{array}{c}\text { Kebajikan \& } \\
\text { Otoriter } \\
\text { (dimensional) }\end{array}$ & $\begin{array}{l}\text { Kepuasan pada Pemimpin, } \\
\text { komitmen pada Tim, Kinerja, } \\
\text { Keinginan untuk tinggal }\end{array}$ & Cheng et al. (2000) \\
\hline Fu, Li, \& Si (2013) & $\begin{array}{l}\text { Kebajikan \& } \\
\text { Otoriter } \\
\text { (dimensional) }\end{array}$ & Kinerja Produk Baru & $\begin{array}{l}\text { Zheng, Zhou, \& Fan } \\
(2000)\end{array}$ \\
\hline $\begin{array}{l}\text { Niu, Wang \& } \\
\text { Cheng (2009) }\end{array}$ & $\begin{array}{l}\text { Kebajikan, Otoriter, } \\
\text { Moral (dimensional } \\
\text { dan interaksi antar } \\
\text { dimensi) }\end{array}$ & Rasa Hormat pada Supervisor & Farh \& Cheng (2000) \\
\hline $\begin{array}{c}\text { Pellegrini \& } \\
\text { Scandura }(2006)\end{array}$ & Paternalism & Kinerja & $\begin{array}{c}\text { Pellegrini \& Scandura } \\
\text { (2006) }\end{array}$ \\
\hline $\begin{array}{c}\text { Pellegrini, } \\
\text { Scandura, \& } \\
\text { Jayarman }(\mathbf{2 0 1 0})\end{array}$ & Paternalistik & $\begin{array}{c}\text { Kepuasan Kerja, Komitmen } \\
\text { Organisasional }\end{array}$ & $\begin{array}{c}\text { Pellegrini \& Scandura } \\
\text { (2006) }\end{array}$ \\
\hline Sheer (2012) & $\begin{array}{l}\text { Kebajikan, Otoriter, } \\
\text { Moral (dimensional } \\
\text { dan keseluruhan) }\end{array}$ & $\begin{array}{l}\text { Loyalitas pada Personal, Loyalitas } \\
\text { pada Organisasi, Kepatuhan, } \\
\text { Komitmen, Kepuasan Kerja, } \\
\text { Kepuasan pada Pemimpin, } \\
\text { Kepuasan pada Hubungan }\end{array}$ & Cheng et al. (2000) \\
\hline $\begin{array}{c}\text { Wu, Hsu \& Chen } \\
(2002)\end{array}$ & $\begin{array}{c}\text { Otoriter } \\
\text { (dimensional) }\end{array}$ & Kepuasan Kerja & $\begin{array}{c}\text { Cheng, Chou \& Farh } \\
\text { (2000) }\end{array}$ \\
\hline Wu, et al. (2012) & $\begin{array}{l}\text { Kebajikan, Otoriter, } \\
\text { Moral } \\
\text { (dimensional) }\end{array}$ & Kinerja, PKO & Farh \& Cheng (2000) \\
\hline $\begin{array}{l}\text { Xiao-Ping Chen, et } \\
\text { al. (2014) }\end{array}$ & $\begin{array}{l}\text { Kebajikan, Otoriter, } \\
\text { Moral } \\
\text { (dimensional) }\end{array}$ & Kinerja Karyawan & Cheng et al. (2000) \\
\hline
\end{tabular}

Sumber: Data Diolah (2021)

Perilaku kepemimpinan paternalistik akan menciptakan pertukaran sosial antara pemimpinndan karyawan, dimana hal tersebut membuat kepemimpinan paternalistik memiliki pengaruhnpositif terhadap kinerja karyawan (Chen et al., 2011). Perilaku pemimpin yang menunjukkan perhatian dan kepedulian terhadap kesejahteraan karyawan memiliki pengaruh positif terhadap kinerja tugas karyawan. Lebih lanjut, salah satu perilaku yang ditunjukkan kepemimpinan paternalistik adalah memimpin dengan memberikan contoh sehingga perilaku pemimpin akan diikuti oleh karyawan. Perilaku perhatian dan kepedulian akan diikuti karyawan dengan menunjukkan hal tersebut kepada rekan kerja yang juga merupakan salah satu contoh dari perilaku kinerja kontekstual yang tinggi. Ketika kepemimpinan paternalistik tinggi maka rasa percaya terhadap pemimpin juga akan meningkat yang berujung pada adanya rasa percaya diri karyawan dalam melaksanakan tugas yang berada di luar tanggung jawabnya. Menyelesaikan tugas rekan kerja yang sedang berhalangan sebagai salah satu ciri kinerja kontekstual akan ditunjukkan karyawan. Hal ini karena melihat perilaku pemimpin yang juga menunjukkan hal serupa (seperti; membantu orang lain) atau menjadikan pemimpin sebagai panutan, sehingga karyawan percaya pemimpin akan mendukung jika perilaku tersebut juga diterapkan karyawan (Chen et al., 2011). 
Rasa percaya pada pemimpin akan menghasilkan peningkatan pada kepatuhan karyawan terhadap peraturan yang berlaku, mendukung perubahan organisasi dan meningkatkan kontribusi karyawan dalam bentuk kinerja, keinginan untuk menunjukkan perilaku yang baik sebagainkaryawan. Hal tersebut kemudian menjelaskan bahwa ketika seorang pemimpin mampu menciptakan rasa percaya karyawan maka akan membuat karyawan juga menunjukkan kinerja kontekstual yang tinggi seperti mematuhi peraturan dan prosedur yang berlaku.

\section{Pengaruh Kepemimpinan Paternalistik dan Kinerja Tugas dan Kinerja Kontekstual Karyawan}

Kinerja tugas terkait erat dengan tugas dan tanggung jawab formal organisasi. Jika dikaitkan dengan perilaku kepemimpinan paternalistik di mana para pemimpin akan memiliki peran dalam memberikan perhatian dan arahan mengenai pengembangan karir demi kebaikan karyawan (Wang \& Cheng, 2010), maka kinerja tugas karyawan akan meningkat karena bimbingan dari pemimpin. Selain itu, menurut Chan \& Mak, (2012), perilaku kebajikan yang ditunjukkan oleh kepemimpinan paternalistik dianggap menjadi elemen penting dalam meningkatkan kinerja karyawan. Hal ini sejalan dengan Pellegrini \& Scandura, (2008) yang menyatakan bahwa perilaku kebajikan akan memenuhi kewajiban peran pemimpin di hadapan karyawan, yang membantu karyawan dalam membangun kelompok kerja yang lebih produktif.

Kepemimpinan paternalistik juga menunjukkan integritas dan kepentingan publik daripada kepentingan pribadi yang dipandang sebagai perilaku kepemimpinan yang baik (Niu et al., 2009) perilaku kepemimpinan paternalistik ini akan memotivasi karyawan untuk terikat dalam hubungan pertukaran sosial dimana ketika karyawan merasa terikat dalam hubungan pertukaran sosial yang tinggi mereka akan merasa berkewajiban untuk membalas perilaku yang diterima dengan meningkatkan upaya dalam melaksanakan pekerjaan yang diberikan sehingga akan mempengaruhi kinerja karyawan (Chen et al., 2011). Perilaku kepemimpinan kapitalistik juga akan meningkatkan kepatuhan karyawan terhadap perintah atau tugas yang diberikan (Sheer, 2012 \& Cheng et al., 2004). Kinerja tugas karyawan akan meningkat karena perilaku tegas dan menuntut pemimpin akan membuat karyawan mudah dalam menangkap tugas yang ditugaskan. Studi empiris sebelumnya yang meneliti kepemimpinan paternalistik dan kinerja tugas terbatas pada pengaruh dimensi (Chen et al., 2011; Sheer, 2012a; Simon, 2008). Namun, dalam penelitian ini diyakini bahwa kombinasi perilaku tiga dimensi kepemimpinan paternalistik akan mempengaruhi kinerja tugas karyawan. Selain itu, studi (Simon, 2008) menjelaskan bahwa perilaku pemimpin yang menunjukkan perhatian dan kepedulian terhadap kesejahteraan karyawan berpengaruh positif terhadap

Hipotesis 1: Kepemimpinan paternalistik berpengaruh positif terhadap kinerja tugas karyawan.

Cheng et al. (2004) menggambarkan ketika seorang pemimpin bertindak layaknya seorang ayah untuk waktu yang lama, pengikut akan merasakan rasa nyaman dan rasa syukur terhadap pemimpinnya. Inilah bentuk ikatan emosional dan timbal balik positif (Blau, 1964). Pada akhirnya karyawan akan merasa bertanggung jawab untuk mengikuti peraturan dan kebijakan organisasi, rasa tanggung jawab dan mendorong tercapainya tujuan organisasi, yang merupakan contoh kinerja kontekstual (Borman \& Motowidlo, 1993; Motowidlo \& Van Scotter, 1994). J.-L. Farh \& Cheng (2000) menjelaskan bahwa kepemimpinan paternalistik yang menunjukkan integritas moral tinggi akan ditanggapi dengan menjadikan pemimpin pemimpin sebagai panutan. Selanjutnya, salah satu perilaku yang ditunjukkan oleh kepemimpinan paternalistik adalah kinerja kontekstual yang tinggi. Perhatian dan kepedulian akan diikuti oleh karyawan dengan menunjukkannya kepada rekan kerja yang juga salah satu contoh perilaku kinerja kontekstual yang tinggi. Bukti empiris juga menunjukkan bahwa perilaku kepemimpinan paternalistik berpengaruh positif terhadap kinerja karyawan yang tidak formal atau tidak terkait langsung dengan tugas pokok karyawan, namun berdampak pada organisasi karena pemimpin dapat menciptakan hubungan pertukaran sosial dengan karyawan (Chen et al., 2011; Simon, 2008).

Hipotesis 2: Kepemimpinan paternalistik berpengaruh positif terhadap kinerja kontekstual karyawan.

\section{Rasa Percaya pada Pemimpin Sebagai Pemediasi Pengaruh Kepemimpinan Paternalistik terhadap Kinerja Tugas dan Kinerja Kontekstual Karyawan}

Menurut Blau, proses rasa percaya pada pemimpin adalah hasil proses hubungan pertukaran sosial (dalam Colquitt et al., 2007). Oleh karena itu, dapat dikatakan bahwa ketika pemimpin mampu menciptakan hubungan pertukaran sosial yang tinggi dengan karyawan, maka akan membuat karyawan memiliki kepercayaan yang tinggi terhadap pemimpin. Burke et al. (2007) juga menjelaskan bahwa rasa 
percaya menjadi proses intervensi yang dapat meningkatkan perilaku, sikap dan hubungan yang penting dalam organisasi. Sejalan dengan itu, Schoorman et al. (2007) menyebutkan bahwa kemampuan, kebajikan dan integritas pemimpin berkontribusi untuk meningkatkan kepercayaan pada pemimpin dalam organisasi. Bukti empiris dari J.-L. Farh \& Cheng (2000) juga mengungkapkan salah satu tanggapan karyawan terhadap kepemimpinan paternalistik adalah kepercayaan pada pemimpin. Ketika kepemimpinan paternalistik dapat mengembangkan persepsi rasa percaya yang positif terhadap pemimpin mereka, hubungan mereka menjadi lebih terikat dalam pertukaran sosial (Blau, 1964), begitu mereka melihat hubungan mereka dengan pemimpin mereka lebih dari pertukaran ekonomi, mereka akan memperoleh keuntungan sosioemosional yang ditawarkan pemimpin paternalistik dalam hubungan. Akibatnya, kemungkinan mereka termotivasi untuk melakukan tugas mereka (Cheng et al., 2013a). Kepemimpinan paternalistik juga menunjukkan integritas tinggi yang dapat mempengaruhi persepsi positif karyawan terhadap keadilan pemimpin (M. Wu et al., 2012), sehingga karyawan akan menunjukkan kinerja tugas yang baik karena mereka tidak khawatir mendapatkan perlakuan tidak adil atau dengan kata lain karyawan akan menjadi diberi penghargaan sesuai dengan penampilan yang mereka tunjukkan.

Hipotesis 3: Kepercayaan pada pemimpin menengahi pengaruh kepemimpinan paternalistik terhadap kinerja tugas.

Ketika kepemimpinan paternalistik tinggi maka rasa percaya pada pemimpin juga akan meningkat yang mengarah pada rasa percaya diri karyawan dalam menjalankan tugas yang berada di luar tanggung jawabnya (kinerja kontekstual) (Schoorman et al., 2007). Bello (2012) mengungkapkan bahwa rasa percaya pada pemimpin akan menghasilkan perbaikan dalam kepatuhan karyawan terhadap peraturan yang berlaku, mendukung perubahan organisasi dan meningkatkan kontribusi karyawan dalam bentuk kinerja, keinginan untuk menunjukkan perilaku yang baik sebagai karyawan. Kemudian dijelaskan bahwa ketika seorang pemimpin mampu menciptakan rasa percaya karyawan, hal itu akan membuat karyawan juga menunjukkan kinerja kontekstual yang tinggi seperti mematuhi peraturan dan prosedur yang berlaku. Menyelesaikan pekerjaan rekan kerja yang absen sebagai salah satu karakteristik kinerja kontekstual yang akan ditunjukkan karyawannya. Hal ini karena mereka melihat perilaku pemimpin yang juga menunjukkan hal serupa (seperti membantu orang lain) atau menjadikan pemimpin sebagai panutan, sehingga karyawan percaya bahwa pemimpin akan mendukung jika perilaku tersebut juga dilakukan oleh karyawan (Chen et al., 2011) Oleh karena itu,

Hipotesis 4: Kepercayaan pada pemimpin menengahi pengaruh kepemimpinan paternalistik terhadap kinerja kontekstual.Bagian ini berisi kajian literatur yang dijadikan sebagai penunjang konsep penelitian. Kajian literature tidak terbatas pada teori saja, tetapi juga bukti-bukti empiris. Hipotesis peneltiian (jika ada) harus dibangun dari konsep teori dan didukung oleh kajian empiris (penelitian sebelumnya).

\section{METODE PENELITIAN}

\section{Responden dan Prosedur}

Penelitian ini menggunakan pendekatan explanatory kuantitatif, dengan menjelaskan pengaruh antara variabel melalui pengujian hipotesis (Neuman, 2006), dengan metode pengumpulan data survei. Data dikumpulkan dari karyawan yang bekerja di organisasi dari berbagai sektor. Teknik pengambilan sampel dalam penelitian ini adalah purposive sampling (Cooper \& Schindler, 2013) dimana pengambilan sampel dilakukan dengan peneliti menentukan sampel dengan kriteria tertentu sesuai dengan tujuan penelitian. Kriteria yang digunakan adalah lama masa kerja karyawan dengan pemimpinnya minimal 1 tahun sehingga karyawan dapat menggambarkan hubungan yang dimiliki dengan pimpinan. Data primer menjadi jenis data yang tersedia dalam penelitian ini, data diperoleh langsung dari responden (karyawan). Metode survei kemudian dipilih sebagai teknik pengumpulan data. Survei dilakukan dengan bantuan koesioner secara daring dan luring sebagai instrumen pengumpulan data.

Setiap responden diminta untuk mengisi kuesioner secara langsung dan link yang diberikan. Dua ratus dua puluh dua (222) kuesioner yang berhasil dikumpulkan namun hanya seratus namun hanya seratus sembilan puluh tiga (193) kuesioner dapat diproses lebih lanjut, yang mewakili tingkat respons sebesar $86 \%$. Mayoritas responden adalah perempuan, 126 orang (65\%). Responden dengan rentang usia 24 sampai 29 tahun menjadi paling banyak, 142 orang (73\%). Tingkat pendidikan sarjana menjadi 
yang paling banyak, yaitu 124 orang (64\%), dan untuk kategori lama masa kerja 1-2 tahun terbesar, 137 orang $(70 \%)$. Semua variabel diukur menggunakan persepsi karyawan. Kepemimpinan paternalistik, kepercayaan pada pemimpin, kinerja tugas dan kinerja kontekstual pada awalnya ditulis dalam bahasa Inggris. Semua skala itu kemudian diterjemahkan dari bahasa Inggris ke Bahasa Indonesia. Kemudian terjemahannya dikoreksi oleh kolega. Semua skala diukur dengan menggunakan skala Likert 5 titik (1 = sangat tidak setuju; $5=$ sangat setuju).

Variabel kepemimpinan paternalistik diukur dengan menggunakan instrumen dari Cheng et al. (2013) sebanyak 26 item. Misalnya "pemimpins aya tidak memanfaatkan saya untuk keuntungan pribadi". Koefisien reliabilitas (Cronbach alpha) untuk skala ini adalah 0,826. Variabel kinerja tugas diukur dengan menggunakan pengukuran yang dikembangkan oleh Befort \& Hattrup (2003) dari 8 item pertanyaan. Salah satu contohnya adalah "Saya mampu menghasilkan karya berkualitas tinggi". Koefisien reliabilitas (Cronbach alpha) untuk skala ini adalah 0,882. Kinerja kontekstual diukur dengan menggunakan 16 item pertanyaan yang dikembangkan oleh Motowidlo \& Van Scotter, (1994). Salah satu contohnya adalah "taat petunjuk bahkan saat pemimpin tidak ada di sana". Koefisien reliabilitas (Cronbach alpha) untuk skala ini adalah 0,876. Rasa percaya pada pemimpin diukur dengan menggunakan 11 item pertanyaan yang dikembangkan oleh McAllister (1995). Salah satu contohnya adalah "Rekan kerja saya yang lain, yang pernah berinteraksi dengan pemimpinsaya akan menganggapnya dapat dipercaya". Koefisien reliabilitas (Cronbach alpha) untuk skala ini adalah 0,878.

\section{HASIL DAN PEMBAHASAN}

Konstruk validitas dalam penelitian ini dilakukan dengan konfirmatori faktor analisis (CFA). Dengan metode rotasi varimax digunakan dalam analisis faktor sehingga akan menghasilkan nilai loading faktor dari masing-masing item pertanyaan untuk mengetahui apakah item tersebut valid atau tidak sebagai alat ukur dari konstruks yang sedang diinvestigasi.

Ada dua variabel dependen dalam penelitian ini, sehingga peneliti harus melakukan analisis faktor secara terpisah untuk masing-masing variabel dependen. Akibatnya, dua putaran analisis faktor untuk variabel kinerja tugas dan tiga putaran untuk variabel kinerja kontekstual dilakukan. Hal ini dilakukan karena ada item pertanyaan yang tidak memenuhi nilai pemuatan dan juga tidak berkelompok pada faktor yang sesuai atau cross loading. Oleh karena itu, peneliti kemudian memutuskan untuk mengeliminasi item pertanyaan dan melakukan analisis faktor kembali sampai semua butir telah mengelompok pada faktor-faktor yang sesuai dengan teori dan variabel dalam penelitian ini. Tabel 2 menunjukkan rangkuman hasil pengujian validitas dimana terdapat beberapa item yang dapat digunakan dan item yang tidak dapat digunakan karena tidak memenuhi role of tumb yang telah ditentukan dalam melakukan analisis faktor.

Tabel 2

Hasil Faktor Analisis

\begin{tabular}{clc}
\hline Variabel & \multicolumn{1}{c}{ Item yang digunakan } & $\begin{array}{c}\text { Item yang } \\
\text { dieliminasi }\end{array}$ \\
\hline \multirow{2}{*}{ Paternalistik } & BL: $1,2,3,4,5,6,7,8,9,10,11$ & - \\
& ML: $1,4,5,6$ & ML: 2,3 \\
& AL: $4,5,7,9$ & AL: $1,2,3,6,8$ \\
\hline Rasa Percaya pada Pemimpin & RP: $1,2,3,6,7,8,9,10,11$ & RP: 4,5 \\
\hline Kinerja Tugas & KT: $1,2,3,4,5,6,7,8$ & - \\
\hline Kinerja Kontekstual & KK: $3,5,6,7,8,10,12,13,15,16$ & KK: \\
& & $1,2,4,9,11,14$ \\
\hline
\end{tabular}

Sumber: Data Diolah (2021)

Dalam pengujian hipotesis kita mengikuti empat langkah Baron \& Kenny (1986) untuk menguji pengaruh pemediasi. Hasil langkah 1 sampai langkah 3 disajikan pada Gambar 1. Dapat dilihat bahwa kepemimpinan paternalistik memiliki pengaruh positif dan signifikan terhadap kinerja tugas $(\beta=.329$; $\mathrm{t}=3.303 ; \mathrm{p}=.000$ ). Dengan demikian, Hipotesis 1 menyatakan bahwa kepemimpinan paternalistik berpengaruh positif terhadap kinerja tugas dalam penelitian ini didukung. Hal ini menunjukkan bahwa kondisi pertama dari tes mediasi telah terpenuhi. Gambar 1 juga menunjukkan bahwa variabel kepemimpinan paternalistik memiliki pengaruh positif dan signifikan terhadap rasa percaya pada 
pemimpin $(\beta=.789 ; \mathrm{t}=17.792 ; \mathrm{p}=.000)$. Hal ini menunjukkan bahwa kondisi kedua pengujian mediator telah terpenuhi. Selanjutnya, Gambar 1 menunjukkan variabel rasa percaya pada pemimpin memiliki pengaruh positif dan signifikan terhadap kinerja tugas $(\beta=.496 ; \mathrm{t}=7.914 ; \mathrm{p}=.000)$. Hal ini juga menunjukkan bahwa kondisi ketiga pengujian mediasi telah terpenuhi.

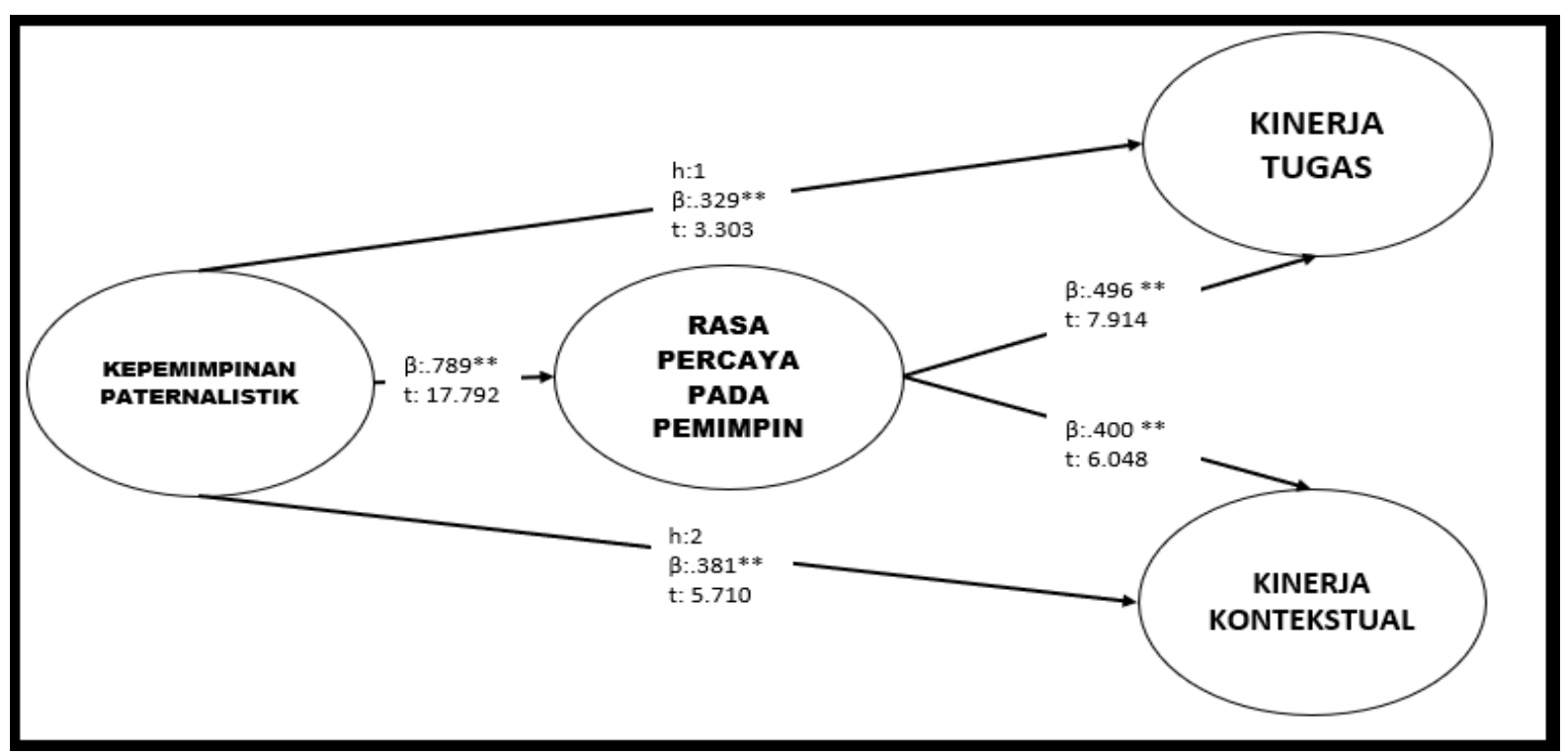

Gambar 1

Hasil Pengujian Hipotesis

Hipotesis 3 mengungkapkan rasa percaya pada pemimpin yang memediasi pengaruh kepemimpinan paternalistik terhadap kinerja tugas. Hasil regresi menunjukkan pengaruh kepemimpinan paternalistik $(\beta=.329 ; \mathrm{t}=3.303 ; \mathrm{p}=.001)$ mengalami perubahan hasil regresi terhadap kinerja tugas namun masih dalam taraf signifikan (nilai $p \quad 0.001 \leq 0.05$ ) setelah variabel kepercayaan $(\beta=.237 ; \mathrm{t}=2.381 \mathrm{p}=.018)$ dimasukkan sebagai mediasi. Ini menjelaskan bahwa variabel rasa percaya pada pemimpin memediasi secara parsial pengaruh kepemimpinan paternalistik terhadap kinerja tugas. Berdasarkan hasil tersebut dapat disimpulkan bahwa hipotesis 3 tidak didukung sepenuhnya karena hanya mediasi parsial.

Gambar 1 juga menunjukkan, bahwa kepemimpinan paternalistik memiliki pengaruh positif dan signifikan terhadap kinerja kontekstual $(\beta=.381 ; \mathrm{t}=5.710 ; \mathrm{p}=.000)$. Berdasarkan hasil tersebut, dapat disimpulkan bahwa hipotesis 2 didukung. Hal ini menunjukkan bahwa kondisi pertama dari pengujian mediasi telah terpenuhi. Gambar 1 juga menunjukkan bahwa kepemimpinan paternalistik berpengaruh positif dan signifikan terhadap rasa percaya pada pemimpin $(\beta=.789 ; \mathrm{t}=17.792 ; \mathrm{p}=.000)$. Hal ini menunjukkan bahwa kondisi kedua pengujian mediasi telah terpenuhi. Gambar 1 menunjukkan rasa percaya pada pemimpin memiliki pengaruh positif dan signifikan terhadap kinerja kontekstual $(\beta$ $=.400 ; \mathrm{t}=6.048 ; \mathrm{p}=.000)$. Hal ini juga menunjukkan bahwa kondisi ketiga pengujian mediasi telah terpenuhi. Hipotesis 4 menyatakan bahwa rasa percaya pada pemimpin memediasi pengaruh kepemimpinan paternalistik terhadap kinerja kontekstual. Tahapan dalam pengujian mediasi hipotesis 4 juga telah terpenuhi (lihat gambar 1 ). Hasil regresi menunjukkan perubahan pengaruh kepemimpinan pateralistik $(\beta=0,173 ; \mathrm{t}=1,615 ; \mathrm{p}=0,108)$ terhadap kinerja kontekstual menjadi tidak signifikan ( nilai p $0,108>0,05)$ setelah rasa percaya pada pemimpin dimasukkan sebagai pemediasi $(\beta=0,263$; $=2,457 ; \mathrm{P}=0,015)$. Hal ini menunjukkan bahwa pengaruh kepemimpinan paternalistik terhadap kinerja kontekstual dimediasi penuh oleh rasa percaya pada pemimpin. Oleh karena itu, dapat disimpulkan bahwa hipotesis 4 didukung.

Temuan penelitian ini menunjukkan bahwa tiga dimensi kepemimpinan paternalistik (kebajikan, otoriter, dan moral) juga ditemukan dalam konteks organisasi di Indonesia. Hal ini sejalan dengan temuan penelitian Irawanto, et al, 2014 yang menemukan perilaku kepemimpinan paternalistik dengan model 3 dimensi pada konteks organisasi sektor publik khusunya yang dikelola oleh pemerintah. Selain itu bersama-sama atau menjadi keseluruhan dapat memberikan gambaran umum tentang kepemimpinan paternalistik (Glick \& Fiske, 2021; Wagstaff et al., 2015). Hasil uji korelasi tiga dimensi 
kepemimpinan paternalistik menunjukkan korelasi yang signifikan. Selain itu, hasil uji reliabilitas menunjukkan nilai Cronbach alpha yang tinggi (0.876). Temuan ini berbanding terbalik dengan penelitian Sheer (2012) yang mengungkapkan bahwa variabel kepemimpinan paternalistik dengan menggunakan pengukuran skor total tidak dapat digunakan karena memiliki nilai reliabilitas rendah dan adanya korelasi antar dimensi yang tidak signifikan. Oleh karena itu, dalam penelitian ini pengukuran keseluruhan kepemimpinan paternalistik dinilai lebih baik daripada pengukuran dimensi.

Temuan dari hasil pengujian pengaruh kepemimpinan paternalistik terhadap kinerja tugas karyawan juga terkonfirmasi sejalan dengan penelitian Wang \& Cheng (2010) yang menjelaskan bahwa pemimpin memiliki peran penting dalam memberikan perhatian dan arahan dalam pengembangan karir karyawan, pengembangan karir yang sangat erat hubungannya dengan kinerja tugas karyawan. Lebih lanjut, perilaku kepemimpinan paternalistik seperti kebajikan akan menjadi elemen penting dalam peningkatan kinerja karyawan (Chan \& Mak, 2012).

Pemimpin dapat mendorong perilaku positif karyawan terutama kinerja tugas dengan meningkatkan perilaku kepemimpinan paternalistik yang menunjukkan ketegasan, kebajikan dalam bingkai integritas moral. Hal ini disebabkan pada dasarnya karyawan akan termotivasi untuk membalas perlakuan yang menguntungkan karena ada rasa hutang dan kewajiban untuk membalas perlakuan seseorang yang telah membantunya. (Gouldner, 1960 dalam Cheng et al., 2013). Selain itu, perilaku kepemimpinan paternalistik juga mampu meningkatkan kepatuhan terhadap tugas yang diberikan (Cheng et al., 2004; Sheer, 2012). Kinerja tugas yang sangat berkaitan dengan masa kerja (seperti, gaji, penempatan dan penugasan) membuat karyawan fokus untuk melakukan tugas yang menjadi tanggung jawab formalnya untuk menghindari penilaian buruk terhadap karyawan, hal inilah yang memberikan justifikasi bahwa perilaku kepemimpinan paternalistik mampu mendorong karyawan untuk meningkatkan kinerja tugas mereka.

Pengaruh positif kepemimpinan paternalistik juga ditemukan pada kinerja kontekstual karyawan pada penelitian ini. Temuan ini sejalan dengan penelitian Chen et al. (2014)bahwa tidak hanya kinerja yang sifatnya formal namun juga pada kinerja yang sifatnya tidak formal yang berdampak bagi organisasi dapat dipengaruhi oleh perilaku kepemimpinan paternalistik. Lebih lanjut Simon (2008) perilaku kepemimpinan paternalistik dapat meningkatkan kinerja yang tidak berhubungan langsung dengan tugas inti karyawan (kinerja kontekstual) dikarenakan tingginya pertukaran sosial antara pimpinan dan karyawan. Selain itu J.-L. Farh \& Cheng (2000) juga menemukan bahwa perilaku kepemimpinan paternalistik mampu membuat karyawan menjadikan pemimpin sebagai panutan. Oleh karena itu, perilaku tersebut menunjukkan kepedulian dan perhatian yang ditunjukkan oleh pemimpin akan diimplementasikan pada rekan kerja sehingga dapat mendorong kinerja karyawan kontekstual yang tinggi.

Temuan utama dari penelitian ini adalah memberikan masukan baru terkait bagaimana mekanisme perilaku kepemimpinan paternalistik mempengaruhi kinerja. Pada pengujian hipotesis 3 ditemukan bahwa rasa percaya pada pemimpin memediasi secara parsial pengaruh antara kepemimpinan paternalistik dan kinerja tugas. Mediasi Rasa percaya pada pemimpin dikatakan parsial karena variabel kepemimpinan paternalistik mempengaruhi kinerja tugas secara langsung, ataupun melalui variabel mediasi rasa percaya pada pemimpin. Hal ini kemudian menjelaskan dua model, Pertama, hubungan kepemimpinan paternalistik pada kinerja tugas secara langsung. Perilaku menunjukkan ketegasan, kebaikan hati dan moral yang tinggi dari seorang pimpinan memberikan keyakinan pada karyawan bahwa tugas yang diberikan adalah hal yang baik untuk dirinya, kemudian mendorong karyawan untuk menunjukkan kinerja yang positif. Hal ini sejalan dengan penelitian $\mathrm{M}$. Wu et al. (2012), Chen et al. (2014) dan Pellegrini \& Scandura, (2006) yang menunjukkan pengaruh positif antara kepemimpinan paternalistik dengan kinerja tugas karyawan. Kedua, kepemimpinan paternalistik akan mempengaruhi rasa percaya karyawan terhadap pemimpinnya. Rasa percaya ini kemudian mampu meningkatkan kinerja tugas karyawan. Hal ini sejalan dengan temuan empiris Huang et al. (2010) bahwa semakin tinggi rasa percaya pada pemimpin maka akan membuat karyawan dalam menyelesaikan tugas. Lebih lanjut, rasa percaya pada pemimpin ini juga ditemukan mampu meningkatkan kemampuan karyawan untuk fokus pada tugas yang diberikan (Lance Frazier et al., 2010) dan juga memotivasi karyawan untuk menyelesaikan tugas yang diberikan (Mayer et al., 1995).

Mekanisme lain yang dijelaskan oleh rasa percaya pada pemimpin pada penelitian ini adalah bagaimana kepemimpinan paternalistik mempengaruhi kinerja kontekstual karyawan. Temuan penelitian ini menunjukkan tidak hanya kinerja tugas yang menjadi tugas inti tetapi kepemimpinan 
paternalistik melalui rasa percaya mampu membuat karyawan lebih percaya diri dalam menjalankan kinerja kontekstualnya. Hal ini juga mengkonformasi bahwa perilaku kepemimpinan paternalistik mampu menciptakan hubungan pertukaran sosial yang tinggi dengan karyawan. Hubungan pertukaran sosial yang tinggi akan menghasilkan rasa percaya pada pemimpin (Cheng et al., 2013; (Colquitt et al., 2007). Hal ini juga sejalan dengan M. Wu et al. (2012) yang menyebutkan rasa percaya pada pemimpin menjelaskan kualitas hubungan pertukaran sosial yang terjadi antara pimpinan dan karyawan. Menjadikan pemimpin sebagai panutan atas dasar rasa percaya kemudian bisa membuat karyawan menunjukkan kepedulian dengan rekan kerja yang juga merupakan ciri kinerja kontekstual yang tinggi. Sehingga dapat pemimpin yang menunjukkan perilaku kepemimpinan paternalistik akan meningkatkan rasa percaya karyawannya yang kemudian mempengaruhi kinerja kontekstual karyawan.

\section{KESIMPULAN}

Sampel dalam penelitian ini diambil dari berbagai organisasi di makassar. Oleh karena itu, dapat disimpulkan bahwa perilaku kepemimpinan paternalistik efektif di berbagai sektor organisasi di Indonesia, khususnya di Makassar. Temuan penelitian ini menunjukkan bahwa kepemimpinan paternalistik memiliki pengaruh positif terhadap kinerja tugas dan kinerja kontekstual karyawan. Kebajikan, integritas moral dan ketegasan menunjukkan kepemimpinan paternalistik mendorong karyawan untuk meningkatkan usaha menyelesaikan tugas-tugas yang diberikan. Kepemimpinan paternalistik mampu membuat karyawan melihat tokoh pemimpin mereka sebagai panutan. Oleh karena itu, perilaku tersebut menunjukkan kepedulian dan perhatian yang ditunjukkan oleh pemimpin akan diimplementasikan pada rekan kerja sehingga dapat mendorong kinerja karyawan kontekstual yang tinggi. Kepercayaan pada pemimpin memainkan peran penting dalam menjelaskan bagaimana perilaku kepemimpinan paternalistik mempengaruhi kinerja kontekstual karyawan. Seperti yang telah disebutkan sebelumnya tentang teori kejadian afektif, kinerja merupakan perilaku positif yang dipengaruhi oleh stimulus positif kepemimpinan paternalistik melalui sikap positif kepercayaan yang telah terbentuk sebelumnya.

Penerapan perilaku kepemimpinan paternalistik sangat disarankan bagi organisasi di Indonesia berdasarkan temuan pada penelitian ini. Perilaku pemimpin yang mampu menempatkan diri layaknya anggota keluarga bagi karyawan, memberikan perhatian dan kepedulian tidak hanya dalam konteks kerja namun juga di luar konteks kerja akan direspon positif karyawan dengan rasa percaya pada pemimpin paternalistik yang tinggi dan pada akhirnya memepengaruhi peningkatan kinerja tugas dan kinerja kontekstual karyawan tersebut bagi organisasi. Selain itu, kepemimpinan paternalistik juga harus menunjukkan kedisiplinan dan ketegasan tinggi dalam pengambilan keputusan. Sehingga karyawan dituntut untuk patuh pada aturan dan ketentuan yang ada, serta adanya ketegasan terkait sanksi terhadap karyawan yang melanggar. Lebih lanjut, seorang pemimpin juga harus memiliki integritas moral sehingga tidak terjadi penyalahgunaan kekuasaan. Karena dalam kepemimpinan paternalistik pemahaman bahwa pemimpin memiliki tanggung jawab moral dalam menjaga dan melindungi hak-hak bawahannya adalah hal yang utama. Penjelasan temuan penelitian ini dapat menjadi dasar bagi organisasi untuk mempertahankan perilaku kepemimpinan paternalistik yang dapat meningkatkan rasa percaya karyawan terhadap pemimpin yang berdampak pada upaya peningkatan kinerja tugas dan kinerja kontekstual karyawan.

\section{SARAN}

\section{Saran Praktis:}

1. Secara praktis penelitian ini memberikan gambaran bagaimana pendekatan kepemimpinan paternalistik dapat digunakan dan menjadi salah satu model kepemimpinan yang efektif dalam meningkatkan kinerja tugas dan kinerja kontekstual. Hasil penelitian kami harus ditafsirkan secara hati-hati secara praktis mengingat keterbatasan metodologi berikut. Pertama, Semua item pertanyaan dalam penelitian ini diisi oleh karyawan untuk memungkinkan bias, walaupun dalam penelitian ini bias telah dikurangi dengan membuat responden mengisi secara anonim dan meyakinkan responden bahwa tidak ada yang benar dan yang salah dalam respon yang diberikan (Podsakoff et al., 2003). Dianjurkan untuk penelitian selanjutnya untuk mengendalikan kemungkinan bias dengan mengambil tanggapan dari sumber yang berbeda atau mengambil tanggapan pada waktu yang berbeda (Podsakoff et al., 2003). 


\section{Saran Teoritis:}

1. Sumbangsih penelitian ini hanya menjelaskan hasil perilaku kepemimpinan paternalistik, sehingga disarankan dalam penelitian selanjutnya juga dapat menguji variabel pendahulu kepemimpinan paternalistik. Pendalaman tentang faktor penyebab perilaku kepemimpinan paternalistik masih pelru eksplorasi mendalam pendekatan kualitatif akan memberikan masukan berharga dalam kajian kepemimpinan paternalistik.

2. hasil uji Validitas untuk variabel kepemimpinan paternalistik dari 9 item dimensi otoriter 5 item harus dieliminasi karena tidak memenuhi persyaratan analisis faktor. Hal ini diduga karena pertanyaan yang dikembangkan oleh J.-L. Farh \& Cheng (2000) terlalu negatif, sehingga menghasilkan respon yang tidak sesuai dengan kondisi sebenarnya dari karyawan yang diminta untuk mengukur tingkah laku pemimpin, karena secara psikologis akan mempertahankan atau "bertahan ". Oleh karena itu disarankan untuk penelitian selanjutnya untuk mencoba pengukuran atau pertanyaan lain yang dikembangkan oleh (Wagstaff et al., 2015).

3. Keempat, secara teoritis penelitian ini menjelaskan mekanisme kepemimpinan Paternalistik dan kinerja tugas dan kinerja kontekstual dalam penelitian ini hanya menguji satu variabel mediasi, yaitu pemimpin kepercayaan. Dianjurkan untuk penelitian lebih lanjut untuk menguji mekanisme lain yang mampu menjelaskan pengaruh kepemimpinan paternalistik dan kinerja tugas dan kinerja kontekstual. Variabel komitmen dan persepsi, variabel keadilan, dengan menggunakan teori kejadian afektif dianggap sebagai respon positif yang bisa muncul karena perilaku kepemimpinan paternalistik juga menarik untuk diteliti lebih jauh.

4. Kelima, Pada penelitian ini juga ditemukan adanya korelasi yang tinggi antara kinerja kontekstual dan kinerja tugas. Namun, pada penelitian ini tidak dilakukan analisis lebih lanjut terkait pengaruh keduanya. Mekanisme dugaan pengaruh keduanya adalah kinerja kontekstual yang mampu menciptakan kondisi atau lingkungan kerja yang positif dapat meningkatkan sense of community, yang tergambarkan dengan kepedulian antar rekan kerja serta meningkatnya motivasi untuk mencapai tujuan bersama. Rasa saling memiliki satu sama lain ini akan memicu karyawan tidak hanya meningkatkan komitmen terhadap organisasi tetapi juga akan mampu menciptakan kinerja tugas karyawan yang tinggi. Sehingga disaran untuk penelitian berikutnya untuk melakukan pengujian terhadap pengaruh kedua variabel tersebut.

\section{REFERENSI}

Aycan, Z. (2006). Paternalism. Indigenous and Cultural Psychology, 445-466. https://doi.org/10.1007/0-387-28662-4_20

Baron, R., \& Kenny, D. (1986). The moderator-mediator variable distinction in social psychological research: Conceptual, strategic, and statistical considerations. Journal of Personality and Social Psychology, 51, 1173-1182. https://doi.org/10.1037//00223514.51.6.1173

Befort, N., \& Hattrup, K. (2003). Valuing Task and Contextual Performance: Experience, Job Roles, and Ratings of the Importance of Job Behaviors. Applied H.R.M. Research, 8.

Bello, S. (2012). The impact of ethical leadership on employee job performance.

Blau, P. M. (1964). Exchange \& Power in Social Life. 352. https://books.google.com/books/about/Exchange_and_Power_in_Social_Life.html?id=q hOMLscX-ZYC

Borman, W. C., \& Motowidlo, S. J. (1993). Borman, W.C. and Motowidlo, S.J. (1993) Expanding the Criterion Domain to Include Elements of Contextual Performance. In Schmitt, N. and Borman, W.C., Eds., Personnel Selection in Organization, Jossey Bass, San Francisco, 71- 78. - References - Scientific. Jossey-Bass. https://www.scirp.org/(S(i43dyn45teexjx455qlt3d2q))/reference/ReferencesPapers.aspx? ReferenceID $=1480874$

Borman, W. C., \& Motowidlo, S. J. (2009). Task Performance and Contextual Performance: The Meaning for Personnel Selection Research. Http://Dx.Doi.Org/10.1207/S15327043hup1002_3, 10(2), 99-109. https://doi.org/10.1207/S15327043HUP1002_3 
Burke, S., Sims, D., Lazzara, E., \& Salas, E. (2007). Trust in leadership: A multi-level review and integration. The Leadership Quarterly, 18, 606-632. The Leadership Quarterly, 18, 606-632. https://doi.org/10.1016/j.leaqua.2007.09.006

Chan, S. C. H., \& Mak, W. (2012). Benevolent leadership and follower performance: The mediating role of leader-member exchange (LMX). Asia Pacific Journal of Management, 29(2), 285-301. https://doi.org/10.1007/s10490-011-9275-3

Chen, X.-P., Eberly, M. B., Chiang, T.-J., Farh, J.-L., \& Cheng, B.-S. (2011). Affective Trust in Chinese Leaders: Linking Paternalistic Leadership to Employee Performance. Https://Doi.Org/10.1177/0149206311410604, 40(3), 796-819. https://doi.org/10.1177/0149206311410604

Chen, X.-P., Eberly, M. B., Chiang, T.-J., Farh, J.-L., \& Cheng, B.-S. (2014). Affective trust in Chinese leaders: Linking paternalistic leadership to employee performance. Journal of Management, 40(3), 796-819.

Cheng, B.-S., Boer, D., Chou, L.-F., Huang, M.-P., Yoneyama, S., Shim, D., Sun, J.-M., Lin, T.-T., Chou, W.-J., \& Tsai, C.-Y. (2013). Paternalistic Leadership in Four East Asian Societies: Generalizability and Cultural Differences of the Triad Model. Http://Dx.Doi.Org/10.1177/0022022113490070, 45(1), 80.90. https://doi.org/10.1177/0022022113490070

Cheng, B.-S., Chou, L.-F., Wu, T.-Y., Huang, M.-P., \& Farh, J.-L. (2004). Paternalistic leadership and subordinate responses: Establishing a leadership model in Chinese organizations. Asian Journal of Social Psychology, 7(1), 89-117. https://doi.org/10.1111/J.1467-839X.2004.00137.X

Colquitt, J. A., Scott, B. A., \& LePine, J. A. (2007). Trust, Trustworthiness, and Trust Propensity: A Meta-Analytic Test of Their Unique Relationships With Risk Taking and Job Performance. Journal of Applied Psychology, 92(4), 909-927. https://doi.org/10.1037/0021-9010.92.4.909

Cooper, D., \& Schindler, P. (2013). Business Research Methods: 12th Edition. MCGRAWHILL US HIGHER ED. https://books.google.co.id/books?id=AZ0cAAAAQBAJ

Cummings, G. G., MacGregor, T., Davey, M., Lee, H., Wong, C. A., Lo, E., Muise, M., \& Stafford, E. (2010). Leadership styles and outcome patterns for the nursing workforce and work environment: A systematic review. International Journal of Nursing Studies, 47(3), 363-385. https://doi.org/10.1016/J.IJNURSTU.2009.08.006

Dirks, K. T., \& Ferrin, D. L. (2002). Trust in Leadership: Meta-Analytic Findings and Implications for Trust in Leadership: Meta-Analytic Findings and Implications for Research and Practice Research and Practice Citation Citation. Journal of Applied Psychology, 87(4), 611-628. https://doi.org/10.1037/0021-9010.87.4.611

Farh, J.-L., \& Cheng, B.-S. (2000). A Cultural Analysis of Paternalistic Leadership in Chinese Organizations (pp. 84-127). https://doi.org/10.1057/9780230511590_5

Farh, L. J. L., Cheng, B., Chou, L., \& Chu, X. (2006). Authority and Benevolence: Employees' responses to Paternalistic Leadership in China - HKUST SPD | The Institutional Repository. In China's domestic private firms: Multidisciplinary perspectives on management and performance. https://repository.ust.hk/ir/Record/1783.1-12929

Glick, P., \& Fiske, S. (2021). Ambivalent stereotypes as legitimizing ideologies: Differentiating paternalistic and envious prejudice.

Hofstade. (2020). Country Comparison - Hofstede Insights. Hofstade Insights. https://www.hofstede-insights.com/country-comparison/indonesia/

Huang, X., Iun, J., Liu, A., \& Gong, Y. (2010). Does participative leadership enhance work performance by inducing empowerment or trust? The differential effects on managerial and non-managerial subordinates. Journal of Organizational Behavior, 31(1), 122-143.

Irawanto, D. W., Ramsey, P. L., \& Tweed, D. C. (2012). Exploring paternalistic leadership and 
its application to the Indonesian public sector. International Journal of Leadership in Public Services, 8(1), 4-20. https://doi.org/10.1108/17479881211230637

Kerrissey, M. J., \& Edmondson, A. C. (2020). What Good Leadership Looks Like During This Pandemic. HBR. https://hbr.org/2020/04/what-good-leadership-looks-like-during-thispandemic

Lance Frazier, M., Johnson, P. D., Gavin, M., Gooty, J., \& Bradley Snow, D. (2010). Organizational justice, trustworthiness, and trust: A multifoci examination. Group \& Organization Management, 35(1), 39-76.

Mayer, R. C., Davis, J. H., \& Schoorman, F. D. (1995). An integrative model of organizational trust. Academy of Management Review, 20(3), 709-734.

McAllister, D. (1995). Affect- and Cognition-Based Trust as Foundations for Interpersonal Cooperation in Organizations. Academy of Management Journal, 38, 24-59. https://doi.org/10.5465/256727

Motowidlo, S., \& Van Scotter, J. (1994). Evidence That Task Performance Should Be Distinguished From Contextual Performance. Journal of Applied Psychology, 79, 475480. https://doi.org/10.1037/0021-9010.79.4.475

Neuman, W. L. (2006). Social research methods qualitative and quantitavie approach (6th ed.). Upper Saddle River Pearson. - References - Scientific Research Publishing. In Pearson (6th ed.). Pearson. https://www.scirp.org/(S(351jmbntvnsjt1aadkozje))/reference/referencespapers.aspx?ref erenceid $=689078$

Niu, C.-P., Wang, A.-C., \& Cheng, B.-S. (2009). Effectiveness of a moral and benevolent leader: Probing the interactions of the dimensions of paternalistic leadership. Asian Journal of Social Psychology, 12(1), 32-39. https://doi.org/10.1111/J.1467839X.2008.01267.X

Pellegrini, E. K., \& Scandura, T. A. (2006). Leader-member exchange (LMX), paternalism, and delegation in the Turkish business culture: An empirical investigation. Journal of International Business Studies, 37(2), 264-279.

Pellegrini, E. K., \& Scandura, T. A. (2008). Paternalistic Leadership: A Review and Agenda for Future Research: Https://Doi.Org/10.1177/0149206308316063, 34(3), 566-593. https://doi.org/10.1177/0149206308316063

Podsakoff, P., MacKenzie, S., Lee, J.-Y., \& Podsakoff, N. (2003). Common Method Biases in Behavioral Research: A Critical Review of the Literature and Recommended Remedies. The Journal of Applied Psychology, 88, 879-903. https://doi.org/10.1037/00219010.88.5.879

Schoorman, F., Mayer, R., \& Davis, J. (2007). An Integrative Model of Organizational Trust: Past, Present, and Future. Academy of Management Review, 32. https://doi.org/10.5465/AMR.2007.24348410

Sheer, V. C. (2012). In Search of Chinese Paternalistic Leadership: Conflicting Evidence From Samples of Mainland China and Hong Kong's Small Family Businesses. Management Communication Quarterly, 27(1), 34-60. https://doi.org/10.1177/0893318912458212

Simon, C. C. H. (2008). Paternalistic leadership styles and follower performance: examining mediating variables in a multi-level model. [Hong Kong Polytechnic University]. https://theses.lib.polyu.edu.hk/bitstream/200/818/1/b21900152.pdf

Sonnentag, S. (2002). Psychological management of individual performance. 516.

Wagstaff, M. F., Collela, A., Triana, M. del C., Smith, A. N., \& Watkins, M. B. (2015). Subordinates' perceptions of supervisor paternalism: a scale development. Journal of Managerial Psychology, 30(6), 659-674. https://doi.org/10.1108/JMP-10-2012-0287

Wang, A.-C., \& Cheng, B.-S. (2010). When does benevolent leadership lead to creativity? The 
Jurnal Value, 16 (2), Hal. 453 - 466

moderating role of creative role identity and job autonomy. Journal of Organizational Behavior, 31(1), 106-121. https://doi.org/https://doi.org/10.1002/job.634

Wu, M., Huang, X., \& Chan, S. C. H. (2012). The influencing mechanisms of paternalistic leadership in Mainland China. Asia Pacific Business Review, 18(4), 631-648. https://doi.org/10.1080/13602381.2012.690940

Wu, Y.-C., \& Tsai, P. J. (2012). Multidimensional Relationships between Paternalistic Leadership and Perceptions of Organizational Ethical Climates: Http://Dx.Doi.Org/10.2466/01.17.PR0.111.5.509-527, 111(2), 509-527. https://doi.org/10.2466/01.17.PR0.111.5.509-527 